\title{
Rūta Žarskienè
}

ruta@1lti.lt

Institute of Lithuanian Literature and Folklore

Vilnius

\section{Brass Ensembles and Brass Bands in the Traditional Culture of Samogitia Region, Lithuania}

\author{
Dęte orkiestry i zespoły $w$ tradycyjnej kulturze Żmudzi, Litwa
}

\begin{abstract}
In this article, the primary focus is the tradition of brass bands and orchestras in the lifestyles of Samogitia's towns and villages in the 20th-21st century. This music-making from Lithuania's western region (Lith. Žemaitija) is no doubt related to the development of Lithuania's musical culture as a whole. Therefore, on the basis of historical sources, the author briefly covers the development of ensembles in the Grand Duchy of Lithuania. The formation of brass ensembles' tradition was particularly impacted by the celebrations of Catholic Church holidays and solemn processions (particularly in the 17th-18th century), and later - manor orchestras and music schools (end of the 18th-19th century). It was in Samogitia that music-making with brass instruments thrived until the very beginning of the 21 st century. The author, on the basis of data collected mainly during fieldworks, reveals the role of brass bands in this region's folk piety, family and community customs, this tradition's changes.
\end{abstract}

Key words: brass ensembles, brass bands, Samogitia, Grand Duchy of Lithuania, Lituania, church feasts, funerals, Samogitian Calvary, Catholic hymns

Streszczenie: $\mathrm{W}$ artykule główny nacisk położono na tradycję zespołów i orkiestr dętych w życiu miast i wiosek Żmudzi w XX i XXI wieku. Muzyka z zachodniego regionu Litwy jest niewątpliwie związana z rozwojem litewskiej kultury muzycznej jako całości. Dlatego też, sięgając do źródeł historycznych, autorka w skrócie opisuje rozwój orkiestr w Wielkim Księstwie Litewskim. Na powstanie tradycji orkiestr dętych szczególnie wpłynęły obchody świąt katolickich i uroczyste procesje (zwłaszcza w XVII I XVIII wieku), później także funkcjonowanie dworskich orkiestr i szkół muzycznych (koniec XVIII I XIX wiek). Na Żmudzi muzyka instrumentów z mosiądzu rozwijała się do samego początku XXI wieku. Autorka, na podstawie danych zebranych głównie podczas prac terenowych, ujawnia rolę orkiestr dętych w religiności ludowej tego regionu, zwyczaje rodzinne i wspólnotowe oraz zmiany zachodzące w tradycji.

Słowa klucze: orkiestry dęte, zespoły dęte, Żmudź, Wielkie Księstwo Litewskie, Litwa, święta kościelne, pogrzeby, kalwaria żmudzińska, pieśni katolickie

Tłumaczenie: Klaudyna Michałowicz

When talking about Samogitia's brass bands, we should keep in mind that their development is closely related to all of Lithuania's culture. Lithuania's cultural situation is very closely related to the musical processes taking place in the West and Central Europe. 
Already in the Middle Ages, at the residences of Lithuania's rulers, and later, at the palaces of noblemen, Catholic Church holidays included the most modern instruments of the time, ensembles and orchestras played fashionable music. During the Baroque period, wind ensembles were small in size (usually consisting of oboe-type instruments, bassoon, flutes, trumpets, French horns, serpents etc.). Wind orchestras flourished during the French Revolution and during the years of the Napoleonic wars. Over the first half of the $19^{\text {th }}$ century, chromatic valved brass instruments of the saxhorn family (tuba, althorn, tenor, baritone and others) were invented, while the trumpet and French horn were improved (Urniežius 2003, 2007). These instruments were added not only to wind orchestras, but also to the symphonic orchestras of the late Romantic period. The orchestras that performed at the palaces of the aristocrats, in the cities and towns, played a major role in the formation of folk brass band tradition, which live on in Samogitia to this day.

Research for this paper is based both on historical sources, previous works, and on material from fieldwork in different parts of Samogitia made by the author in 2004-2017, the author's interviews, as well as correspondence with informants who had lived in Samogitia.

\section{Development of wind ensembles and orchestras in the Grand Duchy of Lithuania}

Historical sources note that already in the late $14^{\text {th }}$ century the GDL had certain wind ensembles / orchestras that may have been military purpose as well. Lithuania's ruler, Vytautas the Great, had an orchestra of whistlers (flutists), which would play for visitors at the palace and accompany the duke on his journeys (Jurkštas 1970). It is known that in 1429 the Roman emperor Sigismund was welcomed in Luck, the castle of Vytautas the Great, with the sounds of trumpets and various musical instruments (Batūra 1966: 51). Albinas Batavičius and Méčius Miknevičius, researchers of GDL military orchestras, believe that in the end of the $14^{\text {th }}$ century - early $15^{\text {th }}$ century military music sounded during the most varied occasions: signing of peace treaties, welcoming of honoured guests, celebrations, when welcoming and seeing off foreign messengers etc. According to the authors, already in the $14^{\text {th }}$ century music of this style was a part of not only military, but also secular culture ${ }^{1}$ (Batavičius, Miknevičius 2001: 52-53). Once Lithuania

\footnotetext{
${ }^{1}$ In 1477, when Lithuania's Grand Duke Casimir welcomed at his Trakai residence the Venetian messenger Ambrosio Cantorini, many trumpeters played. Alexander, who inherited the throne from Casimir, together with his wife Helen, very much enjoyed music. During Alexander's rule, the palace was full of musicians and singers. In 1502, the palace ensemble consisted of seven trumpeters, two whistlers, and a drummer (timpanist) (Čaplinskas 2002: 36).
} 
was officially Christianised ${ }^{2}$, brass and percussion instrument music were included in Catholic Church rituals and celebrations.

Wind instruments became particularly popular in the $16^{\text {th }}-18^{\text {th }}$ century, when the GDL had not just a state army - great private armies were also supported by the most influential noble families: Radziwiłł, Sapieha, Oginski. There is no doubt that these armies, or maybe even their troops, had musicians. They would not only play the trumpets as a way to convey messages, but also during various festivities at the residences of their patrons and when visiting elsewhere, as well as during Church holidays and processions. For example, in 1730, at Zhirovichi (Slonim district, in modern-day Belarus), when crowning the miraculous painting of Virgin Mary, a grand procession came from the Radziwiłł county town of Myra. It included "for their safety, a band of Janissaries soldiers, with their drums and music, came along, and their performance drew the attention of all. Cannon salutes sounded between the music played, and they were shot by the soldiers and the city's craftsmen guilds" (Griciūtè-Šverebienè 2011: 211). In the Baroque period, with the aim of maximum effect, loud wind and percussion instruments were particularly in favour, as well as exotic instruments from foreign lands. With trumpet signals the people of the city were invited to listen to the magistrate's rulings and the court's decisions. The herald would trumpet on the steps of the town hall and later - at each gate of the city. Craftsmen guilds, which also participated in the city's festivities, had their own trumpeters and drummers as well (Trilupaitienè 1995: 115). In Vilnius, the Corpus Christi celebrations organised by the Jesuits were unique in their particular splendour and solemnity: processions (where not only Catholics, but also Orthodox Christians were required to participate) included triumph chariots with living images, hymn-singers, musicians, cannon fire - many people of various faiths gathered to see them, not only from the city, but the surrounding areas as well. ${ }^{3}$ The main participants of these processions - hymn singers, musicians, readers - were students from the Vilnius Academy, founded in 1579 by the Jesuits. There is no doubt that the Celebration of Corpus Christi

\footnotetext{
${ }^{2}$ The Grand Duke of Lithuania, Mindaugas, was baptised in 1251, and Lithuania was declared a kingdom by Pope Innocent IV. In 1253, Mindaugas was crowned king of Lithuania and his wife Morta became queen. After he was assassinated in 1263, Lithuania returned to paganism. While the Lithuanian state began expanding to the east and joined the already-baptised Slavic tribes (Kievan Rus), part of the eastern Lithuanian nobility adopted the Orthodox faith. Lithuania with all its inhabitants was officially Christianised into the Roman Catholic faith in 1387 by the King of Poland, Jogaila (Pl. Władystaw II Jagietto), and his cousin Vytautas (Lat. Alexander Vitoldus), Grand Duke of Lithuania. Samogitia was Christianised in 1413, as this region was officially reclaimed from the Teutonic Order to Lithuania after the battle of Grunwald in 1411 (Vardys 1997: 39-173, Gidžiūnas 1991: 131-138).

${ }^{3}$ The 1587 Corpus Christi procession surpassed in grandeur, solemnity, theatricality all of the other processions that had taken place in the city. This event drew many onlookers - not just Catholics, but representatives of other religions as well (Čaplinkas 2002: 49).
} 
was also celebrated, accompanied by the sounds of music, in Samogitia (Kražiai and Pašiaušè) where members of the Jesuit society were established. According to data from Church historian Paulius Rabikauskas, at the college in Pašiaušè (founded in 1654), along with languages and other sciences, music was also taught, as it was crucial for Mass and more festive celebrations. In 1688, the church installed an organ and military drums (Lat. tympana campestria) (Rabikauskas 1961: 368). The ensemble (orchestra) was founded sometime in the 1720s and flourished especially in the 1730s-1740s, as in 1730 several new French horns were purchased, while in 1746 - a new tuba, cornum, lutes, oboes. ${ }^{4}$ The orchestra, which was mainly made up of the college's students, participated in the town celebrations (Rabikauskas 1961: 368-369).

The festivities of this period were celebrated with great pomp not only in the largest cities, palaces of nobles, and dioceses, but also in remote parishes. Documents from the $17^{\text {th }}-18^{\text {th }}$ century show that churches, monasteries, brotherhoods had musical instruments that they used in processions, pilgrimages, etc. Normally churches used to have pairs of these musical instruments: two trumpets, two French horns and two kettle-drums ${ }^{5}$, or even more (Griciūtè-Šverebienè 2011: 135-138). Churches and monasteries founded fraternity associations, which were very popular at the time; those that did not have their own musicians would invite them from elsewhere. For example, in Samogitia, trumpeters from Alsèdžiai were invited to play at a nearby town, Lieplaukè, and for playing during the feasts of St. George and the Holy Ascension and Trinity, they were paid seven gold coins, and for playing during nine annual festivals the same musicians were paid 20 gold coins from the budget of the brotherhood (Griciūtè-Šverebienè 2011: 137-138). Therefore, we can suppose that the people of Lieplauke had a sort of agreement with the musicians from Alsèdžiai, as it was clear that they were hired all the time. It is interesting to note that today in Samogitia, if a church-village or small town didn't have their own trumpeters, they would be invited from the neighbouring parish, just as in the $18^{\text {th }}$ century.

\section{Music-making at Calvarias, feasts and other church celebrations}

In particular, Samogitian Calvary (Lith. Žemaičiu Kalvarija) played a significant role in the formation of the folk tradition of brass bands in Samogitia. Samogitian Calvary was famed for its miraculous painting of the Virgin Mary with Baby Jesus, and in early July of each year a Feast, devoted to the Visitation of the Virgin Mary or the Great

\footnotetext{
${ }^{4}$ Paulius Rabikauskas presents also the Latin names for these instruments - nempe tuba, cornua, fides, hoboe.

${ }^{5}$ This is also confirmed by the 1820 Tytuvenai church and monastery visitation act. It mentions one pair of trumpets and two damaged kettle-drums (Griciūtè 2004: 297).
} 
Samogitian Calvary Feast, would take place. Since its very establishment ${ }^{6}$, the middle of $17^{\text {th }}$ century, this place has been visited by many pilgrims. According to the famous Lithuanian writer of the $19^{\text {th }}$ century, Bishop Motiejus Valančius, parishioners led by the priests would travel to the feast with drums, trumpets, flags, altars (Valančius 1972: 358-359). The solemnity and loud noise made by these processions is evidenced by the expenses for travel to Samogitian Calvary. For example, Alsèdžiai parish, led by the pastor, would travel on foot with a cross, flags, altars, drums and trumpets. For the gunpowder, saltpetre, sulphur and ammunition paper he paid 49 golden coins (Lith. timpa), for the band accompanying the procession - six golden coins, for cannon fire - five golden coins. The order at such processions was upheld by special overseers - maršalka (Griciūte 2002: 14). Even though large processions were banned in the second half of the $18^{\text {th }}$ century $^{7}$, pilgrimages to this place never ceased.

For the pilgrims who visited Samogitian Calvary, textbooks for the walking the Way of the Cross were written. From these books people would learn what prayers to recite and what hymns to sing at each station of the Way (Vitènas 2005: 231). Today we know of the first such book in Lithuanian - the 1681 prayer book compiled by Georgius Kossakowski (promoter for the Samogitian Calvary's Dominican order): Rozancius swęnciausios Maryos Pannos yr saldziausy warda Jezus ${ }^{8}$ [Rosary of the Blessed Virgin Mary and the Sweet Name of Jesus with Necessary Prayers for a Pious Catholic], which was also meant for those people visiting the Stations of Samogitian Calvary. Along with other hymns and prayers, as a separate part of the book Kossakowski presented the prayers and hymns ${ }^{9}$ for the Stations of the Cross, later were called the same as the Way of the Cross - the Samogitian Calvary Hills (Žemaičiu Kalvarijos kalnai) or simply Kalnai. These hymns are still sung and played with brass instruments in Samogitia not only when visiting the chapels, but also during wakes (read more in the section Brass bands in the traditional lifestyle of villages and towns), death date memorials, during Advent and Lent.

\footnotetext{
${ }^{6}$ Samogitian Calvary was the first Way of the Cross in the GDL and the third in the Polish-Lithuanian Commonwealth. It was started to establish in 1737 by Bishop Jerzy Tyszkiewicz (see: Vasiliūniene 2010: 74-99). It is comprised of nineteen chapels that contain twenty stations, called Žemaičiu Kalvarijos kalnai (Engl. Samogitian Calvary Hills) by the people of Samogitia because chapels were built on hills, and believers had to climb them when praying.

${ }^{7}$ When Bishop Jan Dominik Łopaciński learned about the inappropriate behaviour of some pilgrims, in 1763 he banned mass processions to the Great Samogitian Calvary Feast (Valančius 1972: 359).

${ }^{8}$ Rozancius swęnciausios Maryos Pannos yr saldziausy warda Jezus. Teypogi Spafabas apwaykściojima Katnu Katworyjos Ziamayciu Su Madlitwomis yr Giesmiemis to ftuźijęnćiomis (...), Wilniuy Drukarniey K. J. M. Akademi: Metu 1779 (Vaicekauskas 2005: 93).

${ }^{9}$ The chapter was entitled The Bloody Way of Jesus Christ or Prayers Suitable for the Chapels of the Samogitian Calvary (Kossakowski (1849 [1681]: 221-287). This book was published 47 times until the end of $19^{\text {th }} \mathrm{c}$. The origin of these hymns was studied by Lithuanian scholars - litterateur Mikas Vaicekauskas (read in Vaicekauskas 2005) and musicologist Alfonsas Motuzas (read in Motuzas 2003).
} 
With the Tsar's government's active fight against Catholicism ${ }^{10}$ and after the 1863 Uprising, when processions were banned, the solemnity given by brass and percussion instruments at feasts might decrease. Journeys to the feasts at the Samogitian Calvary gained a "second wind" in the early $20^{\text {th }}$ century, when the bans of Russian Empire were lifted, and, particularly after 1918, when Lithuania restored its independent state. People would travel by train from more distant locations, while those from nearby local Samogitian parishes would travel in the company of priests and clerics, with the sounds of kettle-drums and brass band, which accompanied their hymn-singing. ${ }^{11}$ Walking the Samogitian Calvary Hills continued even in the Soviet era. ${ }^{12}$ Participation in feasts, besides the sense of sacral purification, also became a form of resistance against atheisation and was a way of expressing national protest against the Soviet occupation - walking the hills had to be as pompous as possible, with trumpets and processions. This is why the Soviet government would persecute trumpeters. ${ }^{13}$ They would thus try to keep the processions quiet, so that the "Soviet people" wouldn't be disturbed in "building" communism. Persecution by the government didn't stop either the musicians or the pilgrims - rather it was the opposite, they were encouraged to even more actively express their folk piety.

The tradition of music-making began to change at the end of the $20^{\text {th }}$ century when the feasts were flooded with "new" pilgrims - music pedagogues and their students, staff of cultural centres and their collectives, who during the Soviet period could not publicly pray - the self-taught musicians were slowly replaced by professionals. Instrumental variety also appeared - folk group participants and young pilgrims came to the Samogitian Calvary not with traditional brass instruments, but with the kankless (zither-type folk

\footnotetext{
${ }^{10}$ Read more in Merkys (1999: 584-646); Vidmantas (1995: 77).

${ }^{11}$ Read more in Totoraitis (1937: 5-6); Paleckis (1930: 290-291).

${ }^{12}$ During the Soviet era, all monasteries and convents, as well as some churches, were closed, the names of streets, squares and even cities were changed (for example, the town of Žemaičiu Kalvarija was renamed as Varduva) in an effort to erase any association with religious constructs and symbols. In order to suppress the peoples' religiosity and piety, the Calvaries of Vilnius, Vepriai and Beržoras were destroyed; more than once the Hill of Crosses was mowed down to the ground, and attempts were made to close and desacralize the Samogitian Calvary Chapel. In 1953, before the Great Feast, they were given over to the "care" of the local collective farm, and this provoked a major incident: the pilgrims came and arbitrarily removed the door locks from the chapels and, despite attempts by the police to stop them, still walked the Stations of the Cross. Since 1957, so that fewer people would come to the feasts, a number of measures were taken: secular events were organised (during the Great Samogitian Calvary Feast - a Samogitian festival at Lake Plateliai, during the Šiluva feast - celebrations by the river Dubysa etc.), the media attempted to "unmask" the sanctity of these places, and state transport was banned for the pilgrims going there, etc. (Streikus 2006: 340-341).

${ }^{13}$ According to a brass musician (b. 1948) speaking about an incident during the Great Samogitian Calvary Feast in the late 1960s or early 1970s, since musicians stand out from the rest of the people in the cro$\mathrm{wd}$, when they were arrested by police officers they were put in a police car and locked in prison for 24 or more hours (LTRF cd 989/5/).
} 
instrument), guitars etc. ${ }^{14}$ Therefore, even though at the end of the $20^{\text {th }}$ century - beginning of the $21^{\text {st }}$ century the musical tradition of visiting chapels was infused with new trends, there were always those who tried to pray and sing as their parents and grandparents once did.

According to the musicians interviewed during the expeditions, the peculiarity of the feasts in Samogitian Calvary is that they feature music from brass instruments. A man born in Plunge in 1960, who since childhood has participated in the feasts every year, told that usually, especially on weekends, three or four groups of musicians would be waiting in the churchyard. Those groups of pilgrims that didn't have their own trumpeters, or the priest himself, would invite these musicians to play and join them in walking the Kalnai (hills). ${ }^{15}$ According to musicians from the older generation, in the Soviet era the feasts at Samogitian Calvary could have even seven brass bands (consisting of five or six musicians) waiting at the churchyard, and people would wait in line to hire them (LTRF cd 1201/03/). Pilgrims would pay a monetary donation to the musicians for their services. Therefore, when they wanted to earn more, musicians would often walk the Kalnai several times a day. ${ }^{16}$ In the second decade of the $21^{\text {st }}$ century, one can rarely hear at Samogitian Calvary the music of brass bands - there are much fewer musicians, and there are less and less pilgrims who wish to pray with the sounds of trumpets. One musician, born in 1966, tells how the musicians would once go in groups of five, while in recent years there are only two or even less..$^{17}$

The author of the article, on the basis of her observations, stories from interviewees, and earlier archival material, differentiates brass bands into three groups by their functions. The first group - musicians only play. Usually professional musicians are invited to play in official processions, during which the relic of the Holy Cross is carried, and during Mass in the church. The second group - musicians lead prayers, sing and play. Usually self-taught or having some musical education, musicians raised in a traditional

\footnotetext{
${ }^{14}$ In 2001, ethnologist Rita Balkute recorded a group of young pilgrims and their teachers, who accompanied the hymns with kankles, guitars and a small portable drum. When they would stop at each station, a long wooden trumpet was played. Data from the private video archive of R. Balkute.

${ }^{15}$ According to him, people used to arrive on Saturday (in the Soviet era and the early years of the Rebirth). Indulgences were not considered as being received if a person only walked the kalnai once. One had to walk them three times: in the evening, at night, and for the third time - on Sunday, during the day. Trumpeters were usually hired on Sunday. If a person was wealthy - they could hire musicians for Saturday as well (LTRF cd 1151/01/).

${ }^{16}$ Some musicians indicated that they walked Calvary three times during one day, another interviewees - even five times. One musician from the older generation (b. 1931), explained that the church used to be open all night, so pilgrims would go there to rest, pray, sing hymns, which is why sometimes they would walk the Hills at night. Now the church is locked at night and only open at 7:00 in the morning, which is why the tradition of night-time prayers barely exists.

${ }^{17}$ From the archives of the author of the article. Electronic message from 2 September 2013.
} 
environment, of whom at least one knows very well the course of the Stations of the Cross, has a strong voice, leads the groups of pilgrims who "privately" go over the Hills. A midway option is also possible, when the prayers are led by the elders of the group of pilgrims, while the musicians sing and play the Kalnai hymns. ${ }^{18}$

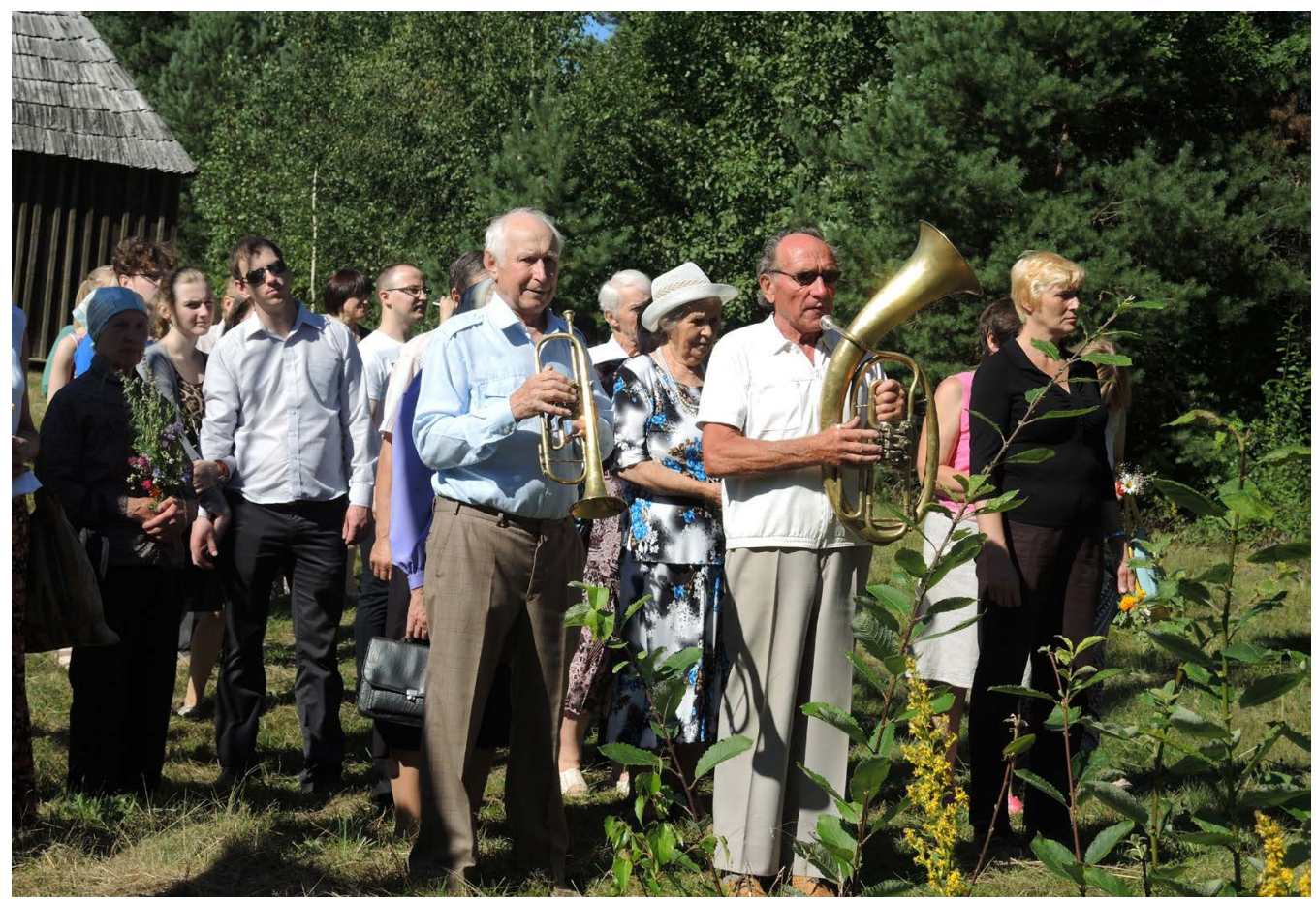

Photo 1 Musicians walking Stations of the Cross together with pilgrims during Feast of the Assumption in Beržoras

During the Feast of the Visitation of the Blessed Virgin Mary (the Great Samogitian Calvary) on 1-12 July, the Way of the Cross is walked, with brass music, in the Calvaries of Mosėdis, Beržoras, Tytuvėnai; however, only invited musicians play there, no one waits to offer their services. By the way, walking the Way of the Cross with trumpets at this Calvary is practised not only during the aforementioned feasts. For example, Beržoras Calvary (14 wooden chapels - Stations of the Cross, established in 1759) in the end of the $20^{\text {th }}-21^{\text {st }}$ century was solemnly walked, with hymn-singers and brass musicians, during other holidays as well - the Feast of St. Anthony, our lady of Mount Carmel (Lith. Škaplierinè), Feast of the Assumption (Lith. Žolinè), Holy Cross, and other holidays.

As was mentioned, in all of the GDL, as well as in Samogitia, in the $17^{\text {th }}-18^{\text {th }}$ century or even much earlier, people would travel to feasts in solemn processions, various

\footnotetext{
${ }_{18}$ About repressions during Soviet times and music making during the Great Samogitian Calvary Feasts, read more in Žarskienè (2017a).
} 
Church feasts would be celebrated. The continuation of these traditions, which have disappeared in other Lithuanian locales, can also be seen in the previous century's traditions of Samogitian folk piety. In the $20^{\text {th }}$ century, small brass bands would play at Church feasts (especially the main ones), Easter Morning Mass, and processions. The Dapšauskas family from Salantai band has played at all the church-village feasts in the districts of Skuodas, Kretinga, Plungé, and especially around Mosédis and Salantai - any and all feasts that take place: "Starting on Easter and ending at Christmas. During the summer there were many (...)"19. Music performed by brass bands was a sign of particular festivity and solemnity in Samogitia and to this day remain a necessary part during Christmas, Pentecost, Corpus Christi and other holidays.

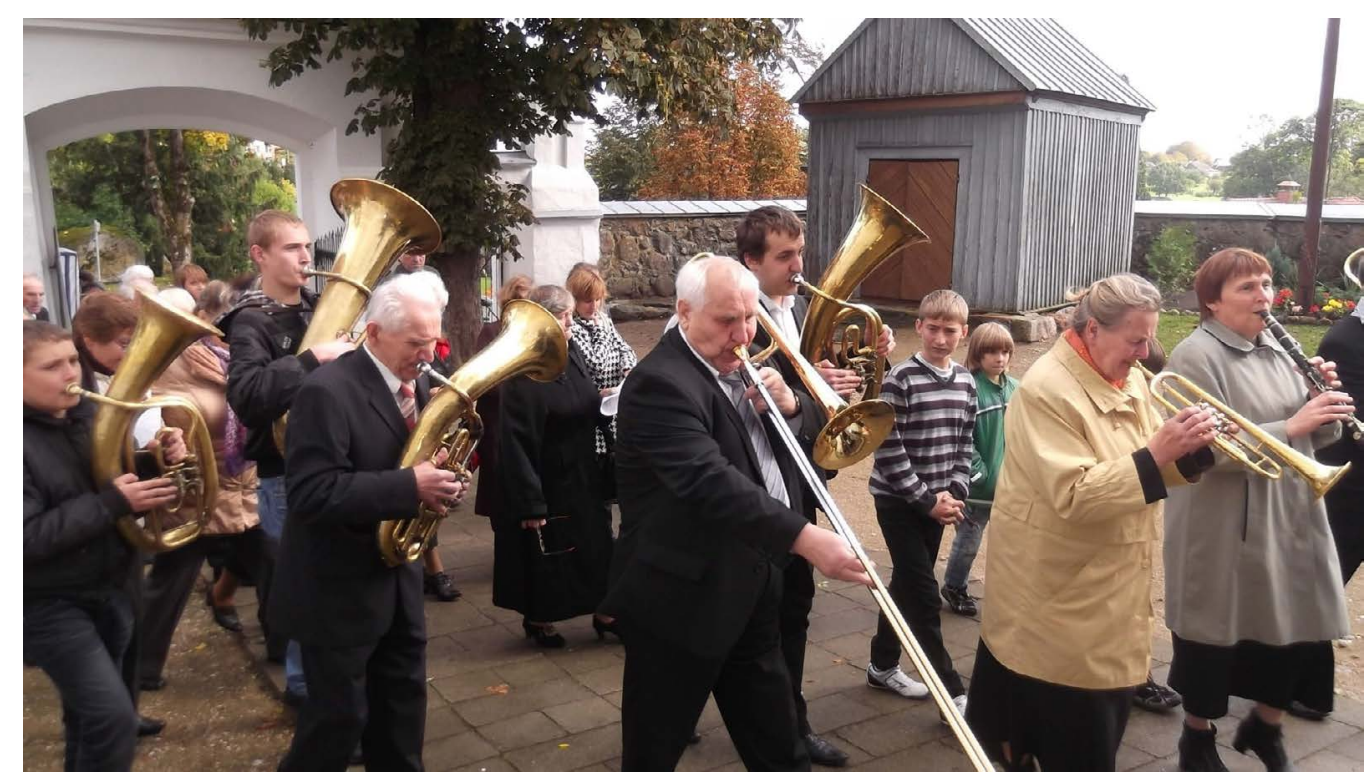

Photo 2 Dapšauskas family orchestra plays during St. Michel Feast in Mosėdis (Skuodas district)

For the Church and for the pious people, one of the most important holidays of the year was Easter, the Resurrection of Jesus Christ. Thus, it had to be properly celebrated. After a quiet, serious Lent ${ }^{20}$, it was important to express joy at the Resurrection, which

\footnotetext{
${ }^{19}$ From the archives of the author of the article. Electronic message from 7 July 2013 and 3 August 2013.

${ }^{20}$ By the way, for Samogitians it was commonplace to play brass instruments during Advent and Lent as well, when neighbours would gather together in the long evenings and sing the Kalnai. The brass bands would participate in singing hymns and Kalnai also during Easter vigil at church. In a manuscript by Juozas Mickevičius, held in the museum in Kretinga, which describes the Easter night traditions in the $19^{\text {th }} \mathrm{c}$. (until 1864), it is described how after the Saturday night service, "the hymn-singers would sit in the pews, sing hymns, the Kalnai with trumpets“ (see Mickevičius 2017). This tradition of night vigil with Kalnai ant brass music lives on even today in Pievenai village (Mažeikiai d.), Rietavas town, and elsewhere.
} 
is why trumpets and kettle-drums sounded. According to an interviewee (b. 1960), "during Resurrection there were kettle-drums and trumpets. When they would play [brass instruments], the earth would shake. The church vaults would shake" (LTRF cd 1151/2/).

Today, at the parish feasts and during Easter, the brass bands would be invited to participate in a procession around the church, play hymns during Mass, and after Mass a march. ${ }^{21}$ At Mass, brass instruments were most often played during Ascension (Sacrifice) and Communion. Nevertheless, brass band were most needed in processions: "The main moment was when we would walk around the church - people would be very happy that we came" - explained one musician from Telšiai (b. 1949) (LTRF cd 989/05/). During the procession around the church, the trumpeters would most often be behind the choir. Now, at all parish feast processions where the Holy Sacrament would be carried, the hymn Viešpatie Jèzau, mūsu Valdove (Our Lord Jesus) would be sung and played (this hymn has been officially approved by Lithuania's bishops). During the Easter morning procession, where people would walk three times around the church (during the feast - once), the hymn Linksma diena mums nušvito (O Joyous Day) was sung.

Brass bands consisting of five or more musicians were usually the ones invited to play during holidays. In the larger cities that had music schools for children (such as Rietavas, Plungè), the students from these schools, teachers and schoolchildren, up to 15 people, would play brass instruments on Easter (LTRF cd 514/03/, LTRF cd 989/02). The traditional composition of a five-six-person brass band consisted of a clarinet, cornet (or two cornettes), tenor (and/or alto), baritone and bass. Now this is changing. The bands include other instruments as well - trombones, saxophone, the baritone replaced by a euphonium. When playing marches, chromatic accordion is played along with the brass instruments.

In Samogitia we can still see one form of the expression of piety - praying with trumpets at the graves of family members during summer-time church feasts and during All Saints Day (November 1), on the eve of All Souls. The latter tradition in the first half of the $20^{\text {th }}$ century was present in other regions of Lithuania ${ }^{22}$, not only Samogitia. However, this territory consistently grew smaller and early in this century the tradition was visible only in northwestern Samogitia. According to one interviewee (b. 1939), in her

\footnotetext{
${ }^{21}$ During the inter-war period, at the great holidays, and sometimes on Sundays, musicians would get so excited that on their way home from church they would play for all their neighbours and wish everyone the best on the occasion of Christ's Resurrection. For example, having played during Mass on Easter, the musicians and singers of Vainutas rural-district were invited by the priest to the rectory where they were given a feast. After being treated at the rectory and regaining their energy, they would visit the homes of nearly everyone in Vainutas town, where, upon approaching a house, "they would play a march and wish everyone the best on the occasion of Christ's Resurrection" (Batavičius 1995: 169).

${ }^{22}$ According to Jūrate Gaideliene, who wrote about a brass band in Panevėžys, old people remember that before WWII "in some places during All Souls' Day bands would stand by the cemetery and play a mournful march for a fee" (Gaidelienè 2002).
} 
youth, the Viekšniai cemetery on the eve of All Saints' hosted several trumpeter groups, mostly consisting of four musicians. After the musicians played at one grave, they would be led to another: "It was very lovely - candles lit, trumpets on one side, trumpets on the other" (LTRF cd 821/2/). During the latter holiday, this cemetery would find three four brass ensembles gathering there from the early morning and waiting for people to invite them to play a hymn and pray at the grave of a loved one.

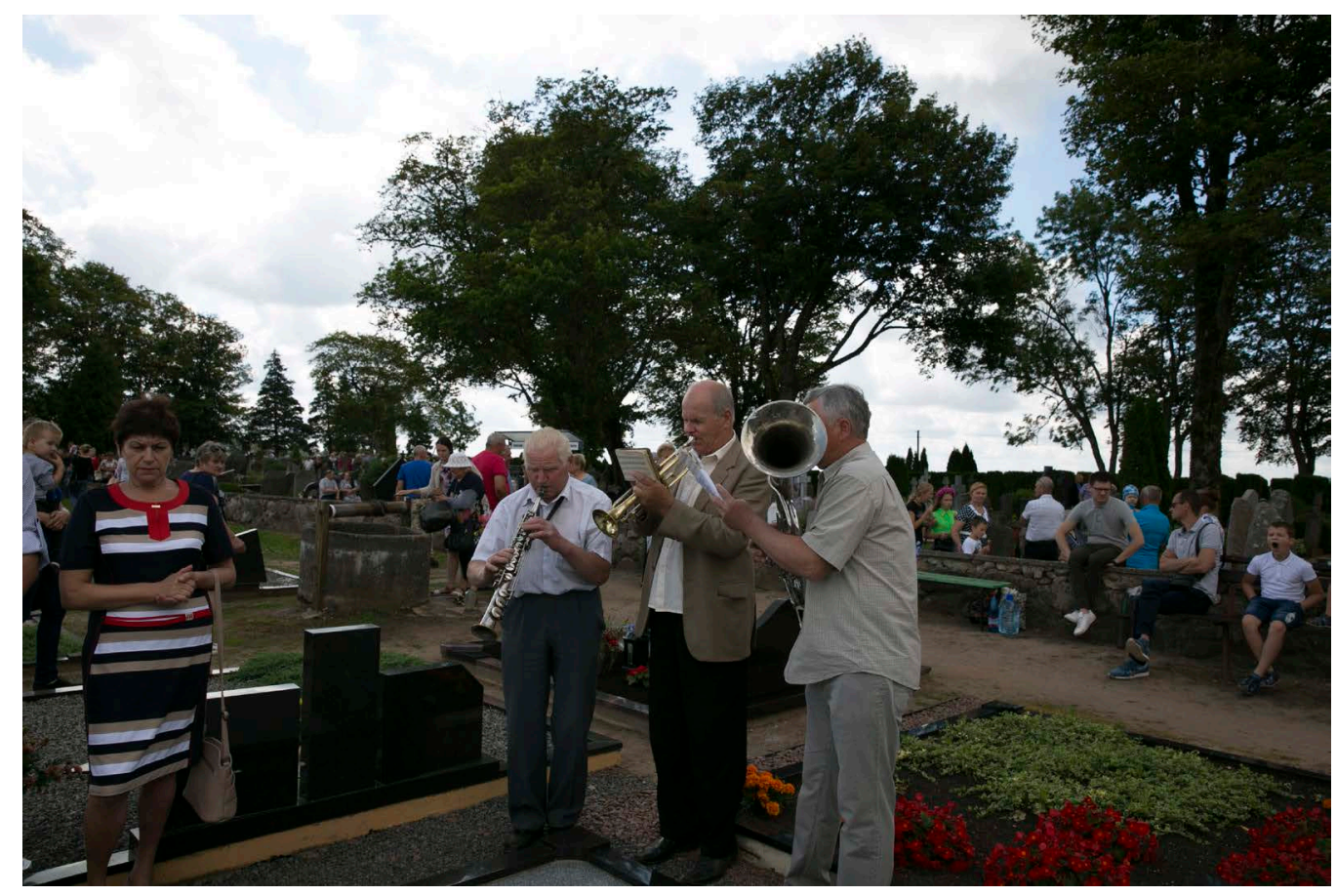

Photo 3 Brass ensembles from Mažeikiai praying at the gravesite in Židikai cemetery during St. Anna feast

During All Saints' Day as well as during feasts taking place in the cemetery in summertime, the main function of trumpeters was to pray at the gravesite. In 2013-2014 the author of this article visited summer feasts in Grūstè and Leckava (Mažeikiai d.), and Ylakiai (Skuodas d.) as well as in 2017 - feasts in Židikai and Vaičiulena (Mažeikiai d.) and observed and fixed the ritual with brass music near a gravesite. Musicians at the grave site would say who the prayers were dedicated to (for example, for all those buried in this grave, for the parents, or by simply saying the names of the deceased) and, crossing themselves, would then say prayers: Our Father, Hail Mary and Eternal Rest. Then they play and sing one verse of a popular hymn (for example Mary, Mary, Oh Mary, Mother of God, Nearer, My God, to Thee, Mary's Name etc.). At the end, they would again perform Eternal Rest, only this time the aforementioned prayer is played and sung in the 
traditional antiphonal manner. All of these "procedures" usually lasted about 3-3,5 minutes. For this the musicians are reimbursed by those who invited them with small monetary donations. The majority of brass ensembles consisted of three or just two musicians, but sometimes there were four. Having asked elder musicians how it used to be before, they indicated that there had to be at least five musicians, while sometimes even six or seven would play and pray at a gravesite (LTRF cd 834/01, 03/). When asked why one needs trumpets in the cemetery, most musicians and the people who hired them replied that this was simply the way it had to be, this was the tradition - some people were brought to tears, as it was like a funeral, while for others it brought back memories. A musician (b. 1962) explained that it might even be enough for the gathered family to simply pray, but since they could invite musicians, this was a sort of "bigger" prayer, an offering from the living to the dead (LTRF cd 834/01/). The research of prayers for the deceased and their honouring during religious holidays revealed that this ritual might be related to the dogma of Purgatory, with roots reaching back to the Baroque period or even earlier (see Žarskienè 2017b).

\section{Brass bands in the traditional lifestyle of villages and towns}

In the $19^{\text {th }}$ century, the traditional musical culture in north-western Samogitia was greatly impacted by the impressive concerts of brass, string and symphonic orchestras of the Plunge and Rietavas manors of Dukes Ogiński. Rietavas was famous for its highly professional brass band, which was established prior to the symphonic orchestra, while the latter was formed from the brass band (Kiauleikyte 2008: 178). The brothers Michał and Bogdan Ogiński also sponsored a music school in which talented children from the surrounding area studied and performed with the orchestra. When the musicians returned to their hometowns during vacations or holidays after their services, they played together with other musicians of their village, taught the more musically inclined village youths, and formed bands. Possibly, village musicians could have acquired brass instruments that were no longer being used in the manors (Žarskienè 2012: 157). This is confirmed by sources that describe the traditions of people in the countryside. Ethnographer Juozas Mickevičius, in his book about Samogitian weddings of the second part of $19^{\text {th }}$ century in Plateliai, Alsèdžiai and Ylakiai surroundings, stated that by 1870 brass instruments became popular at weddings and that brass bands played at the wedding festivities of the wealthier members of the villages (Mickevičius 1933: 70). Other authors mention that brass instruments were played during funeral rituals. ${ }^{23}$

${ }^{23}$ Ethnographer Mečislovas Davainis-Silvestraitis (1889, LMD 229/479/) and priest Antanas Ragaišis (1906) mentioned in their works that brass instruments were used during funeral wakes. 
In the early $20^{\text {th }}$ century, the rapidly more popular brass bands could be heard alongside (or sometimes even replacing) the then-common string and mixed ensembles during Mayday open air dances, weddings, christenings. The local newspaper Vienybe (Unity) of the little town of Eržvilkas from 1908 writes that before there was a brass band, only the fiddle, diatonic button accordion and dulcimer were played at weddings, but now brass bands play at weddings, churches and even funerals (Gasiūnas, 1908). Brass bands were especially good for playing outside at Mayday dance evenings, parties. Interviewees remember that brass bands could play "better and with much more power so that even the fields would ring (...). We could easily 'outrival' the strings, their playing would hardly be heard" - remembered a musician from Vaitimènai village (Šilale district) orchestra (Batavičius 1995: 175). Most often, band leaders would be graduates of the Rietavas or Plunge manors orchestras, church organists, or musicians who had played in the Russian Tsarist military bands. According to the data of Albinas Batavičius, who described the brass bands of Taurage district, one of the oldest orchestras in this district was founded in the 1910s by Antanas Vaičiulis in Bikavenai village (Vainutas rural-district). Vaičiulis came from the Rietavas orchestra. Meanwhile, Ignas Lomsargis, former member of the Tsar's army military orchestra, founded brass band in the town of Žemaičiu Naumiestis upon his return to Lithuania (Batavičius 1995: 73-75, 124-125).

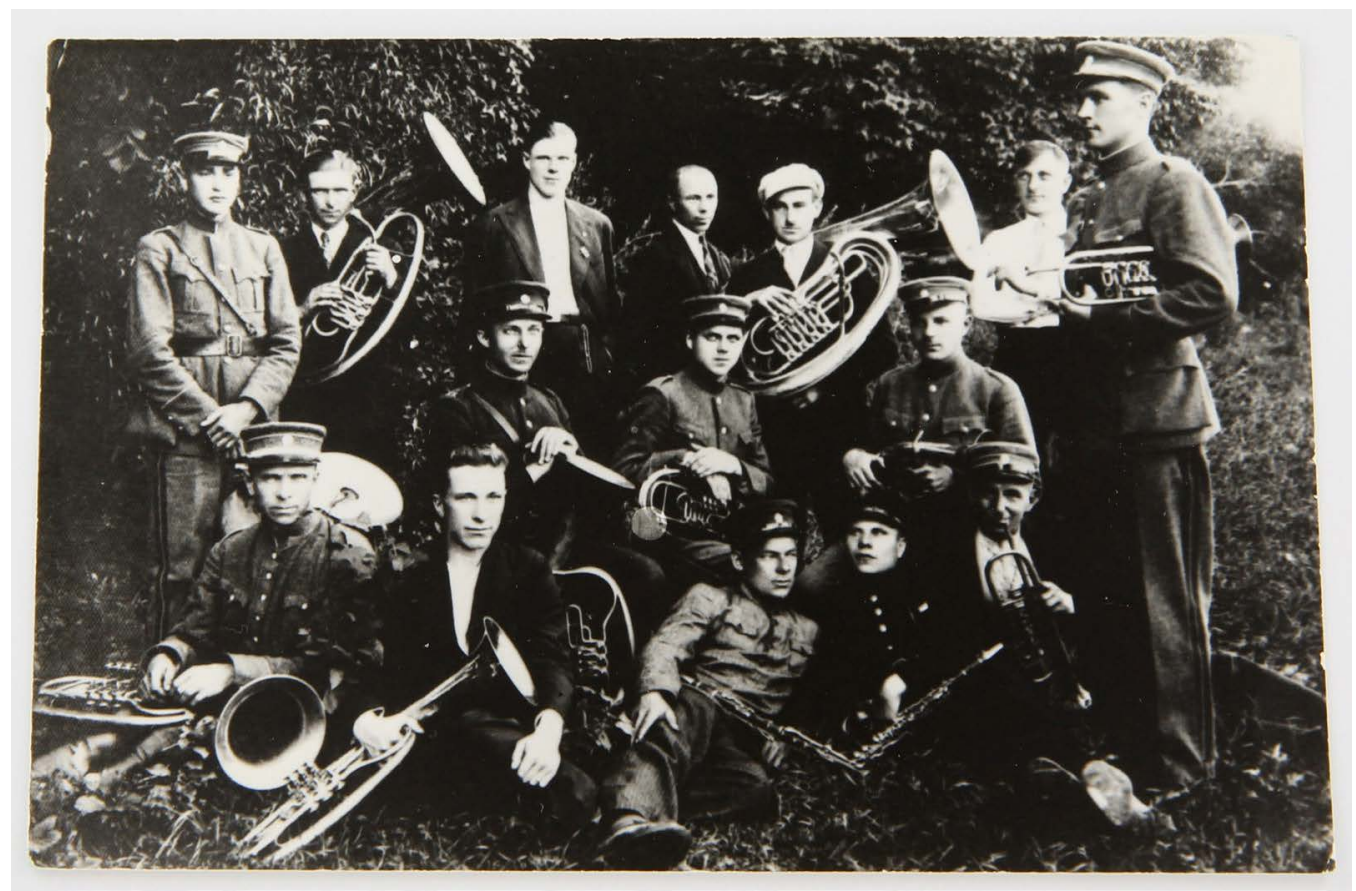

Photo 4 Riflemen brass band from Tauragè (1932) 
In the 1920s-1930s, brass bands music became particularly popular. In Samogitia as well as in the rest of Lithuania, brass bands were formed almost in every military battalion, all organisations (e.g., Young Lithuania, Spring Youth etc.) and unions (firefighters, riflemen, etc.), the labour halls, high schools, churches, and even companies at that time. These bands performed during state celebrations and religious festivals and were often invited to play at wedding parties of town dwellers and wealthy farmers. A real drive to form brass bands also reached Samogitia's countryside - for a larger village to have its own brass band became a matter of honour. Usually fiddlers or accordionists learned to play a woodwind (mostly - clarinet) or brass instrument (mostly - cornet or trumpet) and formed a village band. Since village men themselves did not know how to read notes, they "took lessons" from the musicians of neighbouring parishes, students of the pedagogical or theological colleges, or even hired a bandleader. Despite such "training" of the village musicians, they remained true self-taught amateurs; they played the violin, diatonic button accordion, bandoneon and other instruments by ear and only in the brass bands did they play from the score. Nevertheless, in the villages there were not only individual musicians who could not read notes, but there were also entire brass bands in which several, if not all musicians played by ear (Batavičius 1995: 119, Urbienè 1988, Žarskienė 2012). Many of these brass bands were composed of members of one - or in the case of a larger band - two or three families. One resident of Salantai (b. 1939), in talking about her mother's family, noted that her grandfather was a simple farmer, but he could play any instrument. He had taught all four of his sons to play brass instruments: "My mother's father and four brothers were very good trumpeters" (LTR 7506/33/). In northern Samogitia - Ylakiai, Seda, Židikai - during the pre-war period, the famed Jonušas, Brasas, Vasiliauskas and other family brass bands were formed, which, as younger generation musicians joined, drawing in their neighbours as well, lived on into the Soviet era. ${ }^{24} \mathrm{~A}$ village brass band needed at least 4-6 members. The instruments most often played were: one or two clarinets (cornets), althorn (baritone), baritone (tenor), bass (tuba, helicon) and drum. Some bands played without the drum, only with brass instruments. Another common arrangement was to play with 7 to 9 and sometimes even more musicians. The cost of brass instruments especially in the beginning of the $20^{\text {th }}$ century was out of the price range of simple peasants. However, their enthusiasm was so great that peasants would sell their livestock in order to acquire brass instruments. Of course, the musicians did not simply buy the expensive instruments for their own pleasure. With such a fad of brass music sweeping the country, these instruments were a stable

\footnotetext{
${ }^{24}$ Profiles from ethno-instrumental expeditions, which took place in 1988, of the Non-State Institute of Ethnic Music. Data written down in Mažeikiai district. Material held at the Lithuanian Folk National Centre, Vilnius; Antanas Vasiliauskas' information, written down in 2013.
} 
investment. Musicians expected to make back the money they spent rather quickly by playing at weddings, funerals, festivals and other occasions. Bigger and better village brass bands usually were invited to play at weddings, funerals, open air dances, town and church festivities, etc.

After World War II, when mass deportations began - as did resistant fights of the green partisans - many musicians were deported or killed and village bands were neglected. But the tradition did not die out. During the Soviet occupation period the brass band musicians were persecuted for playing in church as well as at Catholic funerals and at times even fired from their jobs. However, the Samogitians, famed for their conservatism and stubbornness, did not give up. Even when family customs and traditions began to change, and brass bands were no longer desired at weddings and christenings at the end of the $20^{\text {th }}$ century, they remained an integral part of Catholic funerals.

It should be noted that during the Soviet occupation brass bands were sounding during the funerals of important individuals throughout all of Lithuania. In cities, funeral marches led the final journeys of all World War II veterans, Russian-speaking foreign-born persons, and Communist Party members. In rural-places brass bands were organised on all collective farms and their musicians accompanied the funerals not just of the administrators but also of regular collective farm workers. However, an entirely different development occurred in Samogitia where, when compared to other regions, more traditional funeral and mourning rituals have persisted to this day. ${ }^{25}$ Here, even during the Soviet times, brass instruments played melodies of Žemaičiu Kalvarijos kalnai (Samogitian Calvary Hills) or simply Kalnai (Hills) and other funeral hymns at the traditional Catholic funerals - during the night-long vigil and accompanying the deceased to the cemetery.

In Samogitia, brass bands at funerals started to become very popular during the "classical" Soviet era years, i.e. in the 1960s; in the 70s and 80s, their popularity reached its zenith. The use of brass bands at funerals became a matter of great prestige in rural villages, towns and cities. Anyone who could afford it, hired a band: when the trumpets sounded at funerals, it was said that the deceased was "properly honoured". ${ }^{26}$ Musicians played at funerals several times during a week, whereas the more noted brass musicians played almost every day. During fieldwork in Rietavas, a member of a popular brass band (b. 1953) recounted that in one day they led as many as three deceased to the cemetery and added: "we went to the funerals just like to a job, people stood in line to hire us" (LTRF cd 509/01/).

\footnotetext{
${ }^{25}$ Modern ethnological studies also have noted that rituals of traditional funerals and mourning have survived more in Samogitia than in other regions of Lithuania. Read more in Garnevičiūtè (2012), Stumbra (2011).

${ }^{26}$ Data recorded by the author in Vilnius in 2011 from an interview (b. 1948) from the Kretinga district.
} 
The brass band musicians were often invited for the night vigil or a wake, where people stayed up all night next to the deceased and where the Kalnai were sung. The orchestra was also asked to participate on the day of the burial in order to follow the deceased to the church and cemetery. The Kalnai and other funeral hymns were performed with the brass band in the antiphonic manner, i.e. taking turns - either singing or playing. The musicians explained that there were several variants. Most common was this pattern: first stanza or first line ${ }^{27}$ is sung by men, the second - is played by the band, the third - by women, the fourth - by the band. Often the singers did not split up, the first stanza was sung and the second was played by the musicians. This manner persists even when both functions are performed only by the musicians. Usually at funerals often there were five, six or seven players.

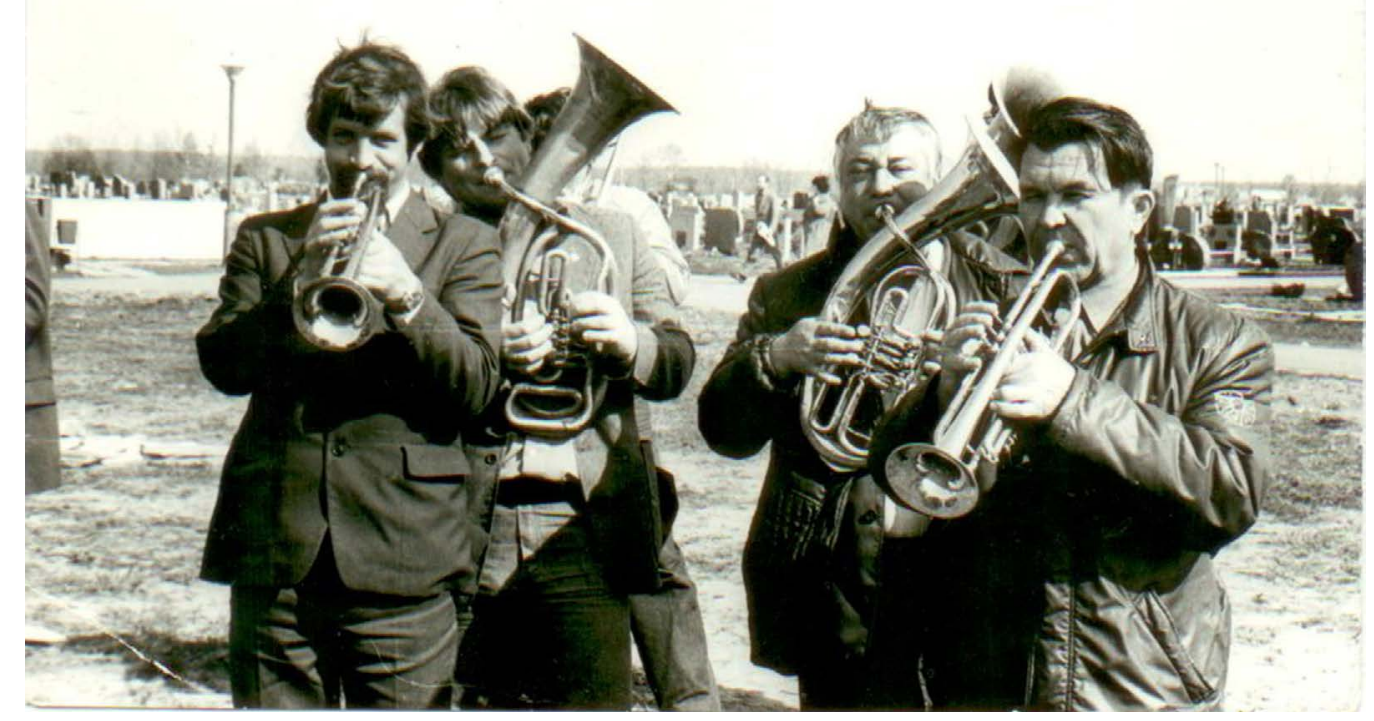

Photo 5 Brass band in funeral in Samogitia (the 1970s)

At the turn of the century, throughout all of Lithuania as well as in Samogitia, there have been many changes both in the vigil practices and in funeral music traditions. The vigil rituals moved to the newly opened funeral parlours and professional companies oversee all the burial concerns. Musicians and pedagogues have joined the ranks of hired funeral musicians. Strong competition has emerged among the various groups that offer

${ }^{27}$ This could be a half stanza as well. 
their hymn singing for funeral services. During field research expeditions musicians told that now, instead of traditional structure of five or seven musicians, only three of them play at funerals. The trio (two trumpets / clarinets and bass or trumpet, tenor and tuba etc.) plays in the funeral processions. But at the night vigil when the Kalnai are sung together with other hymns, one of the brass instruments is replaced by an electronic keyboard or synthesiser (LTRF cd 23/26/). As the older generation steps aside and with the strong influence of television and radio, the musical tastes are changing both in the cities and in the rural areas. ${ }^{28}$ These days, one can hear at Samogitian funerals ensembles of various compositions, sometimes even duets. Brass instruments are often replaced by string and other instruments - one or two kanklès, one or two violin with a keyboard or synthesizer etc. As society grows more secular, prayers for the deceased grow less and less important, which is why even the Kalnai prayers and hymns are shortened or even entirely eliminated. Funeral music is understood not as something to escort the soul of the deceased, but as a pleasant background for those who are gathered at the wake. However, the tradition is constantly changing and renewing itself. This is confirmed by a 2015 expedition in Raseiniai region by the author, where she encountered a brass band of a traditional instrumentation (two trumpets, trombone and tuba). After about 20 years, musicians have once again come together to perform traditional Catholic prayers and hymns at funerals (LTRV 997).

\section{Final remarks}

Today it is difficult to say why in Samogitia the playing of brass instruments is such a deep part of traditional culture and why it lives on to this day, although similar processes had occurred throughout Lithuania. The first occurrences of playing brass instruments are mentioned as taking place in the Vilnius and Trakai residences of rulers and noblemen; trumpets and drums were played in walking the Calvaries of Vilnius and Vepriai, and during the inter-war period brass bands would play in villages and towns throughout Lithuania during May outside dances, weddings, christenings; during the Soviet period bass bands were formed in nearly every collective farm. Why in Samogitia, even during the years of Soviet occupation, did simple people come together into small brass bands and perform religious hymns at Church festivals and funerals? Perhaps this was a result of the popularity of the Great Samogitian Calvary Feast and the tradition of solemnly walking the Stations of the Cross or the manor orchestras and schools that taught many fine musicians and kapellmeisters? Or, perhaps, it was the funeral traditions,

\footnotetext{
${ }^{28}$ For more about the role of brass bands in Samogitian funeral traditions and its change, read in Žarskienè (2013).
} 
full of folk piety, where the Samogitian Calvary Hills (Žemaičiu Kalvarijos Kalnai) is sung to this day? Or the conservatism and stubbornness of the Samogitian people? The study revealed that all the aforementioned factors resulted in music-making with academic brass instruments becoming a part of this region's traditional culture. "Without the brass, there is no funeral" - told a famous jazz saxophonist who originated from Samogitia. Therefore, to this day, the tradition of music-making by brass bands (albeit constantly changing) remains a unique part of Samogitia, differentiating it from Lithuania's other regions.

\section{Bibliography}

Batavičius, A. (1995). Tauragès apskrities dūdų orkestrai (Brass Bands of the Tauragè District). Tauragè: A. Batavičius.

Batavičius, A., Miknevičius M. (2001). Kariniai orkestrai Lietuvos Didžiojoje Kunigaikštysteje (Military Bands in the Grand Duchy of Lithuania). Naujoji Romuva, 3 (536), $52-57$.

Batūra, R. (1966). Muzika ir dainos feodaliniame Vilniuje (Music and Songs in Feudal Vilnius). Kultūros barai, 3 (15), 51.

Čaplinskas, R. A. (2002). Šventès ir iškilmès Vilniuje XVI-XIX amžiuje (Feasts and Festivals in Vilnius in $16^{\text {th }}-19^{\text {th }}$ centuries). Liaudies kūryba, 5, 35-62.

Gaidelienè, J. (2002). Pučiamieji orkestrai: praeitis ir šiandiena (Brass Bands: Past and Present). Panevėžio balsas, February 12, 7.

Garnevičiūtė, R. (2012). Trijų katalikiškų laidotuvių papročių religinė prasmė (XXI a. pradžia) (The Religious Meaning of Three Catholic Funeral Customs - Beginning of $21^{\text {st }}$ c.). Lietuvių katalikų mokslo akademijos metraštis, 36, 133-155.

Gasiūnas, K. (Erž.) (1908). Eržvilkas. Vienybė, 19, May 6 (19), 294.

Griciūtè, L. (2002). Didžiosios žemaičių procesijos (The Great Processions of Samogitians). Žemaičių žemè, 4, 12-14.

Griciūtè, L. (2004). Taikomoji dailè. In: D. Klajumienè (ed.), Tytuvėnų Bernardinų bažnyčia ir vienuolynas (p. 277-302). Vilnius: Vilniaus dailès akademijos leidykla.

Griciūtè-Šverebienè, L. (2011). XVII-XVIII a. bažnytinès procesijos Lietuvos Didžiojoje Kunigaikštysteje (Ecclesiastical Processions in the Great Duchy of Lithuania in $17^{\text {th }}-18^{\text {th }}$ Centuries). Vilnius: Vilniaus dailès akademijos leidykla.

Jurkštas, V. (1970). Vytauto muzikantai (Musicians of Vytautas). Literatūra ir menas, 32, 10.

Kiauleikytė, L. (2008). XVIII a. II pusės-XIX a. muzikinè Lietuvos dvarų kultūra: stiliaus epochų sankirtose (Musical Culture of Lithuanian Manors in the Second Part 
of $18^{\text {th }}-19^{\text {th }}$ Centuries: Crossing Style Epochs). Vilnius: Kultūros, filosofijos ir meno institutas.

Kossakowski, G. (1849) (ed.). Rożanczius swęcziausios Marios Panos yr saldziausi warda Jezusa su rejkalingesniomis małdomis diewabajmingam katalikuj (Rosary of the Blessed Virgin Mary and the Sweet Name of Jesus with Necessary Prayers for a Pious Catholic). Vilnius: Spaustuwi A. Dworcziaus.

Merkys, V. (1999). Motiejus Valančius. Tarp katalikiškojo universalizmo ir tautiškumo (Motiejus Valančius. Between Catholic Universalism and Nationalism). Vilnius: Mintis.

Motuzas, A. (2003). Lietuvos Kalvarijų Kryžiaus kelių istorija. Apeiginiai papročiai ir muzika (History, Rites and Music of Lithuanian Calvaries' Roads of the Cross.). Kaunas: Vytauto Didžiojo universiteto leidykla.

Mickevičius, J. (1933). Žemaičių vestuvès (Samogitian Wedding). Mūsų tautosaka, 7, 47-125.

Mickevičius, J. (2017). Senosios Velykų tradicijos (Old Easter Tradition). Obtained from http://zemaitijosnp.lt/senosios-velyku-tradicijos/.

Paleckis, J. (1930). Lietuvos Jeruzalè - Žemaičių Kalvarija (Lithuanian Jerusalem - Samogitian Calvary). Naujas žodis, 14, August 1, 290-291.

Rabikauskas, P. (1961). 18-ojo amžiaus Lietuvos bruožai. Iš Pašiaušès jėzuitų kolegijos metraščių (Lithuanian Features in $18^{\text {th }}$ Century. From Chronicles of Jesuit College in Pašiaušè). Tautos praeitis. Chicago: Lietuvių Istorijos Draugija.

Ragaišis, A. (1906). Žemaičių Kalvarijos aprašymas (Description of Samogitian Calvary). Vilnius: Vilniaus žinių spaustuvè.

Streikus, A. (2006). Atlaidai Žemaičių Kalvarijoje ir Šiluvoje: jų pobūdis bei reikšmè sovietmečiu (The Feasts in Samogitian Calvary and Šiluva: Their Nature and Significance during the Soviet Era). Lietuvių katalikų mokslų akademijos metraštis, 28, 339-344.

Stumbra, S. (2011). Šermenų apeigos Žemaitijoje: tradicijos ir modernumo problematika (The Problem of Modernity and Tradition in the Funeral Chanditing Tradition in Samogitia). Res Humanitariae, 9, 65-85.

Totoraitis, J. (1937). Žemaičių Kalvarija. Marijampolè: Marijonai.

Trilupaitienė, J. (1995). Jėzuitų muzikinè veikla Lietuvoje (Jesuit Musical Activities in Lithuania). Vilnius: Muzika.

Urbienè, A. (1988). Viekšniškiai grajija ir dainuoja (Viekšniai People Play and Sing). In: D. Krištopaitè (ed.), Aš išdainavau visas daineles (p. 448-460). Vilnius: Vaga. 
Urniežius, R. (2003). Karinis orkestras (Military Band). In: Muzikos enciklopedija, vol. 2 , (p. 123-124). Vilnius: Mokslo ir enciklopedijų leidybos centras.

Urniežius, R. (2007). Pučiamųjų instrumentų orkestras (Wind Orchestra). In: Muzikos enciklopedija, vol. 3, (p. 162-163). Vilnius: Mokslo ir enciklopedijų leidybos centras.

Vaicekauskas, M. (2005). Lietuviškos katalikiškos XVI-XVIII amžiaus giesmės (Lithuanian Catholic Hymns of the $16^{\text {th }}-18^{\text {th }}$ centuries). Vilnius: Lietuvių literatūros ir tautosakos institutas.

Valančius, M. (1972). Žemaičių vyskupystė (Samogitian Bishopric). In: B. Vanagienė (ed.), Raštai, vol. II. Vilnius: Vaga.

Vardys, V. S. (ed.) (1997). Krikščionybė Lietuvoje (Christianity in Lithuania). Chicago: Lietuvos krikščionybės jubiliejaus komitetas.

Vasiliūnienė D. (2010). Žemaičių Kalvarija. Piligriminio centro istorija ir dailè XVII-XIX a. (Samogitian Calvary. The History and Art of the Pilgrimage Center in the 17th-19 th Century). Vilnius: Aidai.

Vidmantas, E. (1995). Religinis tautinis sajūdis Lietuvoje XIX a. antroje pusèje - XX a. pradžioje (National Religious Movement in Lithuania in the Second Part of the $19^{\text {th }}$ Century - First Part of the $20^{\text {th }}$ Century). Vilnius: Kataliku akademija.

Vitėnas, A. (2005). Kančios kelias: istorija, tradicijos ir architektūrinis ryšys su evangeline Jeruzale (Via Dolores: History, Traditions and Architectural Connection with Evangelical Jerusalem). In: A. Butrimas (ed.), Plungės dekanato sakralinė architektūra ir dailè. Plateliai, Beržoras, Gintališkè, Šateikiai, Žemaičių Kalvarija, Gegrẻnai (p. 229-251). Vilnius: Vilniaus dailès akademijos leidykla.

Voveris, V. (2007). Ginkluotosios pajėgos. Istorinè apžvalga (Armed Forces. Historical Overview). In: Visuotinè lietuvių enciklopedija, vol. 12 (p. 206). Vilnius: Mokslo ir enciklopedijų leidybos institutas.

Žarskiene, R. (2012). The Origin, Development and Disappearance of Tradition: Brass Bands in Lithuania. In: P. Richter (ed.), Musical Traditions. Discovery, Inquiry, Interpretation and Application (p. 152-166). Budapest: HAS, Research Center for the Humanities.

Žarskienè, R. (2013). The Role of Brass Bands in Funeral Rituals of Samogitia. In: G. Jänichen (ed.), Studija instrumentorum musicae popularis, vol. 3 (New series) (p. 387-402). Münster: MV-Wissenschaft.

Žarskienè, R. (2017a). Music-making and Folk Piety in Lithuania. Continuity and Change in Performing the Walking of the Stations of the Cross. PULS - journal for ethnomusicology and ethnochoreology, 2, 68-87. 
Žarskienè, R. (2017b). Sounds of Brass Instruments: Functionality, Aesthetics, Meaning. In: G. Jänichen (ed.), SIMP - Studia instrumentoru musicae popularis, vol. 5 (New series) (p. 483-500). Münster: MV-Wissenschaft.

\section{Archival material}

Lithuanian Folklore Archives of the Institute of Lithuanian Literature and Folklore: LMD I (first fund of the Lithuanian Science Society's manuscript collection), No. 229.

Lithuanian Folklore Archives of the Institute of Lithuanian Literature and Folklore, Manuscript Collection: LTR 7506/33/.

Lithuanian Folklore Archives of the Institute of Lithuanian Literature and Folklore, Sound Collection: LTRF cd 23, LTRF cd 514, LTRF cd 509, LTRF cd 821, LTRF cd 834, LTRF cd 989, LTRF cd 1151, LTRF cd 1201.

Lithuanian Folklore Archives of the Institute of Lithuanian Literature and Folklore, Video Collection: LTRV 997.

Lithuanian Folklore Archives of the Institute of Lithuanian Literature and Folklore, Photograph Collection: LTRFt 10000, LTRFt 18930, LTRFt 22285, LTRFt 22575, Bt 0005.

Profiles from ethno-instrumental expeditions, which took place in 1988, of the Non-State Institute of Ethnic Music. Data written down in Mažeikiai district. Material held at the Lithuanian Folk National Centre, Vilnius.

\section{List of photographs}

Photo 1 Musicians walking Stations of the Cross together with pilgrims during Feast of the Assumption. Photo by Rūta Žarskienè, 2015. From the archives LTRFt 18930.

Photo 2 Dapšauskas family orchestra plays during St. Michel Feast in Mosėdis (Skuodas district). Photographed in 2012. From personal album of Jonas Dapšauskas. From the archives LTRFt 22575.

Photo 3 Brass ensembles from Mažeikiai praying at the gravesite in Židikai cemetery during St. Anna feast. Photo by Danute Adomaitienè, 2017. From the archives LTRFt 10000.

Photo 4 Riflemen brass band from Tauragè. Photographed in 1932. From collection of Albinas Batavičius. Bt 0005.

Photo 5 Brass band in funeral in Samogitia. Photographed in 1970th. From personal album of Alfonsas Motuzas. From the archives LTRFt 22285. 
